\title{
Polysèmes
}

Revue d'études intertextuelles et intermédiales

\section{Stillness and Temporality in the Work of Louis} MacNeice

Immobilité et temporalité dans l'œuvre de Louis MacNeice

\section{Karen Brown}

\section{(2) OpenEdition}

\section{Journals}

\section{Electronic version}

URL: http://journals.openedition.org/polysemes/2288

DOI: 10.4000/polysemes.2288

ISSN: 2496-4212

Publisher

SAIT

\section{Electronic reference}

Karen Brown, «Stillness and Temporality in the Work of Louis MacNeice », Polysèmes [Online],

18 | 2017, Online since 30 November 2017, connection on 01 May 2019. URL : http://

journals.openedition.org/polysemes/2288 ; DOI : 10.4000/polysemes.2288

This text was automatically generated on 1 May 2019.

Polysèmes 


\title{
Stillness and Temporality in the Work of Louis MacNeice
}

Immobilité et temporalité dans l'ouvre de Louis MacNeice

\author{
Karen Brown
}

\section{AUTHOR'S NOTE}

An earlier version of this essay was presented at the conference "Silence... and Irish Writing”, Pázmány Péter Catholic University, Budapest (2014), organised by Dr. Michael McAteer. I thank Dr. McAteer for his insightful comments on the text. I also thank the "zero and twelve" research group at the University of St. Andrews for discussing it with me.

Museums offer us, running from among the buses, A centrally heated refuge, parquet floors and sarcophaguses,

Into whose tall fake porches we hurry without a sound

Like a beetle under a brick that lies, useless, on the ground.

Warmed and cajoled by the silence the cowed cypher revives, Mirrors himself in the cases of pots, paces himself by marble lives,

Makes believe it was he that was the glory that was

Rome,

Soft on his cheek the nimbus of other people's martyrdom,

And then returns to the street, his mind an arena 
where sprawls

Any number of consumptive Keatses and dying

Gauls

("Museums", MacNeice 2007, 29, 1. 1-10)

1 To date, only a handful of critics have remarked on the museal aspects of MacNeice's oeuvre. In the context of verbal-visual relationships, MacNeice's friendship with Anthony Blunt is suggestive-according to Edna Longley, it has not yet been "widely appreciated that MacNeice's first intellectual mentor was Anthony Blunt" (Longley 233). Their friendship reveals that MacNeice's engagement with the museum as space and concept was both intense and lifelong, having been interwoven into his intellectual development. As Stallworthy points out, Blunt taught MacNeice to "read, mark, learn and inwardly digest" pictures when they were boys at Marlborough, and they travelled together to Spain over Easter 1936, where they visited the Prado in Madrid (180). In his autobiography The Strings are False, MacNeice recorded:

In my own house at Marlborough College the dominant intellectual was Anthony Blunt, who had a precocious knowledge of art and an habitual contempt for conservative authorities. He was very tall and very thin and drooping, with deadly sharp elbows and the ribs of a famished saint; he had cold blue eyes, a cutaway mouth and a wave of soft brown hair falling over his forehead. His features were far from classical but he had at times a pre-Raphaelite beauty; when he was annoyed he pouted and stuck out his lip, his good looks vanished and sulkiness was all. He had specialized in mathematics, but outraged the masters of the Modern Side by putting most of his energies into a society of his own to which he read papers on Cubism. (MacNeice 1965, 95)

2 The two young men continued to correspond in letters for many years after their school days, and these letters are littered with references to paintings. For example, between 1927 and 1928 when MacNeice was in Merton College, and Blunt a Fellow of Trinity College, Cambridge, MacNeice asked Blunt's advice about framing his "Cézanne Still Life", and reported that he had bought a reproduction of "Van Gogh's bridge". He also invited Blunt over to Oxford to give a lecture on the artist Brueghel, and commissioned an article on modern French art for the student newspaper he edited called Galahad. ${ }^{1}$ These letters provide additional evidence of MacNeice's eclectic reading at the time, counting Walter Pater's essay on "Style", Frazer's The Golden Bough, Wyndham Lewis, and Virginia Woolf's Mrs Dalloway. ${ }^{2}$ In one letter, MacNeice asked Blunt to purchase him a copy of the complete works of Ovid (the Metamorphoses in particular), and those of Virgil, in lieu of some money owed to him. ${ }^{3}$ Their inter-arts endeavours also extended to the men conceiving the idea of an illustrated magazine to be called The Venture, which was to appear in Cambridge in October. Consisting of short stories and verse, woodcuts and articles on music, art and drama, it would be edited by Blunt, H. Romily Fedden and Michael Redgrave, with a contribution by MacNeice in the first number. ${ }^{4}$ Regrettably, the magazine never materialised.

3 It was Blunt who, in a radio portrait of Louis MacNeice (BBC transmission, 7 Sept. 1966), first opened up the idea of MacNeice's visual sensibility when he noted that:

My own contact with Louis depended to a large extent on a particular faculty which hasn't I think been sufficiently emphasized in what's been said and written about him, and that was his astonishing visual sensibility; both to paintings but also simply to things seen, colours of the most curious kinds [...] when he was talking about painters like Brueghel or Blake, [he] showed not only an interest in the content of the literary side, those are admittedly if you like all rather literary 
painters, but an astonishing feeling for the actual visual impression. (Blunt, qtd in Walker 2009, 199) especially the Egyptian rooms, had been of primordial importance for MacNeice's literary imagination. He quotes from the thirteen-year-old schoolboy's diary:

British Museum

January $4^{\text {th }}-$

After 4 P.M. when part of Mus. shut went through Egyptian galleries etc. up staircase to mummy rooms with Louisa [an alias for Elizabeth?]. Egyptian roomsFirst R.-Bodies of prehistoric men baked hard by the sun. Skeletons. Box \& basket burials $-2^{\text {nd }} R$. Mummies \& mummy cases $3^{\text {rd }}$ room later ornamented mummies. During 3 days saw nearly all the rooms including Roman Galleries-(sculptured heads of Julius Caesar, Nero, Titus, Marcus Aurelius, Antonius Pius etc); GraecoRoman Rooms. (copy of Diadamerous, copy of Discobolus, Hermes); Demeter of Cnidus, Ephesus Room; Elgin Room (Thesis \& 3 Fates, bust of Pericles); Phrigaleian \& Werec'd rooms; Mausoleum (statues of Mausoleus \& wife) Egyptian galleries (head of Thothmes III, statue of Ramses II, many black granite statues of Sephet, the fire goddess, stone Sphinx [?] cast of Smet Smet, "Rosetta Stone"... stone sarcophagi, bits of colossal statues; Assyrian Transept. (Stallworthy 67)

Stallworthy remarks: "Many of these objects, sinking into the depths of memory and there preserved as by the peaty waters of an Irish bog, would be exhumed years later for use in poems" (67). Stallworthy does not elaborate on his salient observation, thus initiating the prospects for a new line of enquiry informed by theories of museology and by word and image studies. The text-image investigation into MacNeice's work has been considered by Tom Walker ("Even", 196-213), and is developed in the context of museology by Karen E. Brown (2014, 23-30).

As Elizabeth Loizeaux observes, poetry written in the twentieth century is "fully born of the museum age", and museum and gallery experiences differ among poets according to socio-historical context (21). The specific museums considered in this chapter-the British Museum and the National Gallery in London-were built in the language of classical architecture with their large domed rotundas, portico entrances, and impressive staircases. As Kenneth Hudson has pointed out, the British Museum in particular reinforced and encouraged this classicizing tradition throughout Britain in the nineteenth century, declaring civic pride and cultural standing through the semiotics of museum architecture (Hudson 25-26). In the 1930s, as today, museums acted as a refuge from the noise of the street, providing a space wherein one could think, create and reflect in the manner described by Stuart Sim in his Manifesto for Silence (2007). Poets such as MacNeice may have gone to these museums as places of retreat from the bustle and business of everyday life, believing them to be optimal spaces of stillness in which to seek inspiration. Yet the experience could ultimately take on a moralistic value, as the poet was forced to contemplate epic themes such as suffering or death (Yeats's mortal loss of his friends in "The Municipal Gallery Revisited"), or even a heuristic value as individual struggles or societal malaise were re-enacted within museum walls (Yeats 601-604).

Moreover, objects in modern museums become art works through the modus operandi of display. They are exhibited to encourage prolonged looking, placed in a contextual narrative imposed by the curator. Removed from their original cultural contexts, they have resonance within cultural systems of their original and current environments. Svetlana Alpers calls this aestheticisation of objects the "museum effect" (Alpers 26), while Stephen Greenblatt and Catherine Paul focus on viewers" "resonance and wonder" 
in front of museum objects (Greenblatt 42, Paul 3). Both concepts speak to the idea of an intense immobility in the museal experience. In what follows, I argue that MacNeice's poems offer a critique of the museum as a still and silent refuge from malaise, both personal and historical. At the same time, it will be seen that a complexity exists within MacNeice's writing wherein the museum is experienced as a powerful and layered metaphor, affirming the power of the museal space for him; a space of "intense immobility" linked to the idea of museum-mausoleum (see Bennett; Mansfield 1-8; Preciosi 28-45).

\section{"Like a Beetle Under a Brick"}

The obvious place to begin this enquiry is with MacNeice's early poem "Museums", written in 1933. Here, the reader imagines the poet seeking solace in a museum and playing out his fantasies there. In the poem, MacNeice creates a simile between the museum visitor and a beetle that has hurried into the museum space, "warmed and cajoled by the silence" (MacNeice 2007, 29, 1. 5). The reader visualises the visitor making his way quietly through the galleries of the museum, and filling his imagination with "the nimbus of other people's martyrdom" (1.8) before re-emerging onto the street, his imagination filled with images of "consumptive Keatses and dying Gauls" (MacNeice 2007, 29, 1.10)). In this poem as in others considered here, MacNeice's museums offer spaces of relative stillness where one might escape the noise and bustle of the street, the traffic, and the cold. But why, at this time and in this socio-political context, was museal stillness of such importance to MacNeice? By comparing the buildings to classical temples, medieval cathedrals, and Renaissance palaces, Carol Duncan has drawn attention to the ritualistic experience of museum architecture, demonstrating that "a museum is not the neutral and transparent sheltering space that it is often claimed to be" (Duncan 90). Highlighting the role of ritual in museum experience, and ways in which museums forge a sense of citizenship within a public, Duncan's ideas have special resonance in considering MacNeice's relationship with these spaces when viewed in the socio-political climate of the 1930s. Collectively, his "museum" poems offer a critique of the institution as a sanctuary from wider political unrest in the context of the Second World War, an interpretation equally relevant to W.H. Auden's "Musée des Beaux Arts" (Auden 146-147; Coombes 24-26). ${ }^{5}$

By the eve of the Second World War, MacNeice had been frequenting the British Museum, the London Zoo (discussed in his 1938 book, Zoo), and the original British Museum Reading Room. Founded in 1753, the British Museum was, according to Marjorie Caygill, the first national, public and secular museum in the world, which aimed to belong to the nation and to be, at least in theory, open to all "studious and curious persons" (Caygill 3-4). The iron-framed room was designed with scholars, not the general public, in mind. Constructed in 1855-57 and opened in May 1857, the reading room dome also became one of the sights of London, measuring 140 feet in diameter and containing some 1.14 million cubic feet of space-making it comparable only to the Pantheon in terms of size. ${ }^{6}$ Additionally, the interior design was innovative, accommodating three hundred readers at radially set tables, each reader being made physically comfortable with warming pipes for their feet and air vents in each table (Wilson 118). On the eve of the Second World War, MacNeice describes the reading room as a privileged space in which he and his fellow writers could take refuge. In the context of the 1930s to the 1950s or 
1960s, this may well have been the case for the reading room, in contrast to the contested culture of noise present in the ex-library today (Sim 51). MacNeice recalled: "The summer of 1939 was a steady delirium, the caterpillar wheels of enormous tractors rearing on every horizon. As individuals there was nothing we could do-just mark time or kill it. [...] The British Museum became a sort of club for us. [...] The colonnade of the British Museum is the quintessence of peace" (MacNeice 1965, 208-209). These reflections on the domed haven for writers and the displaced inspired a July 1939 poem called, precisely, "The British Museum Reading Room":

Under the hive-like dome the stooping haunted readers Go up and down the alleys, tap the cells of knowledgeHoney and wax, the accumulation of yearsSome on commission, some for the love of learning, Some because they have nothing better to do Or because they hope these walls of books will deaden The drumming of the demon in their ears. Cranks, hacks, poverty-stricken scholars, In pince-nez, period hats or romantic beards And cherishing their hobby or their doom Some are too much alive and some are asleep Hanging like bats in a world of inverted values, Folded up in themselves in a world which is safe and silent: This is the British Museum Reading Room.

(MacNeice 2007, 690 1. 1-14)

Clearly, for MacNeice the Reading Room played a similar role to the museum in his personal and societal world. Both were sites of intense immobility and refuge and, in the case of the Reading Room, enabled the formation of community among scholars coming from various backgrounds of education and class and all "[h]anging like bats" (MacNeice 2007, 690, 1. 12). Some of the lines above could be interpreted as more negative than positive in an alternating language of life and death ("cherishing their hobby or their doom"; "[h]anging like bats"), reinforcing the museum-mausoleum in MacNeice's writings, and the more portentous aspects of an "intense immobility". Considered in the context of the encroaching war, it should be noted that this "world which is safe and silent" (MacNeice 2007, 690, 1.13) was shrouded in unease, and that this was a peace which could be quickly shattered. For example, an air raid shelter was constructed in the basement of the museum, to which readers in August 1939 could be evacuated in the event of an attack. In the same month, when war with Germany appeared inevitable, the museum and library arranged with the railway companies to remove material by escorted container vans-a process put in place on 24 August when, over the course of two weeks, more than one hundred tons of books, manuscripts, prints, and drawings were moved to Aberystwyth (Miller 334).

11 For MacNeice's part, he spent the remainder of 1939 between Belfast and Dublin, and in February and March 1940, he gave a series of lectures in the United States of America, after which he taught for a time at Cornell University while pursuing a temporary relationship with the American writer Eleanor Clark (MacNeice 1965, 222). ${ }^{7}$ In the USA MacNeice also suffered acute appendicitis, convalescing at Portsmouth Hospital in New Hampshire following his operation (MacNeice 1965, 23-35). Yet he records this period of his career in letters and memoirs as exceptionally happy and productive, as though he were on the brink of a new phase in his work. Most significantly, he wrote two gallery 
poems engaging with the theme of intense immobility at this time: "Picture Galleries" (MacNeice 2007, 760-761) and "The National Gallery" (MacNeice 2007, 258).

\section{MacNeice's Museal Journey in "Picture Galleries"}

12 In 1967, Germain Bazin emphasised the original religious and contemplative context of the museum visit. It is, in his terms, "[a] temple where Time seems suspended, the museum procures for today's man those momentary cultural epiphanies in which, since Gide, he has delighted" (Bazin 7). Written in the spirit of a Bazinian epiphany, MacNeice's 1940s poem "Picture Galleries" speaks to definitions of "musing" in a museum-from the old French muser, meaning "pondering" or "loitering", "reflecting in silence", "being mentally abstracted or absorbed in thought", and "looking or gazing in contemplation" ( Chambers Dictionary 991). "Musing", in "Picture Galleries," is understood as a temporal process related to "strolling", through which the poet has the sensation of a muffled stillness in the form of a suspension of time: ${ }^{8}$

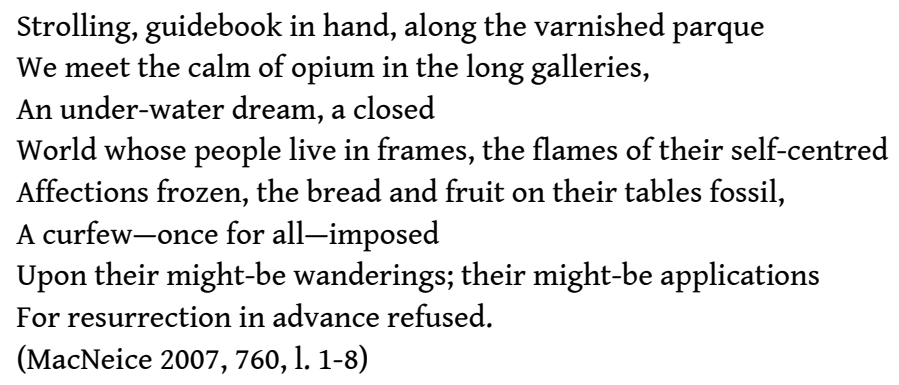

"Picture Galleries" is the poem in which MacNeice engages most strongly with the tradition of ekphrasis associated with Auden's "Musée des Beaux Arts". In MacNeice's poem, the museum is experienced as an "under-water dream, a closed / World" and the people the poet sees there "live in frames [...] / Affections frozen". For this poet, picture galleries are, like museums and the British Museum Reading Room, a site of intense refuge, and in "Picture Galleries", the poet's visit induces a sense of calm and escapism from everyday life: "the calm of opium in the long galleries, / An under-water dream" (MacNeice 2007, 760, 1. 2).

This appearance of time suspended (to characterise "dreamtime") in the poem reminds us of descriptions of ekphrasis by Wendy Steiner as a "pregnant moment", after Gotthold Ephraim Lessing (Steiner 41-48). It also brings to mind Rhoda L. Flaxman's and Viola Hopkins's concepts of a "framing device" located within the text (Flaxman 1-5; Hopkins 561). In the words of Murray Krieger, ekphrasis oscillates between a desire for "the spatial fix" and the "freedom of the temporal flow" (10). We see this throughout the first stanza of "Picture Galleries": still-life subjects ("the bread and fruit on their tables") become fossilized with a "curfew [...] imposed". The potential for movement ("might-be wanderings [...] might-be applications,") is left frustrated, because these objects are ultimately denied the possibility of resurrection. In this instance, the poem is apprehended both temporally, from one line to the next, and spatially, as the rhyming system that creates echoes between line endings. The use of four stanzas balanced by a regular rhyming scheme also gives an illusion of control or freeze-framing, but the poem demonstrates the narrative impulse characteristic of ekphrasis, as the poet is impelled to animate the image through narrative and rhythm. Indeed it is this rhythm that at once draws MacNeice to prolonged viewing of art works, and torments him because of it: 
Yet were violent monsters, whom the retiring ocean

Left embedded in sandstone: Michelangelo's tortured

Urge to God, Greco's fugue of fire,

Goya's sleight-of-hand that fooled his patrons, Blake's ingenuous

Usurpation of reality, Daumier watching the bubbles rising

From mouths of the drowned; panic, desire,

Fantasy, joy of the earth-the rhythm lurks in the canvas, sometimes

If we look long, is more than we can bear.

(MacNeice 2007, 760, 1. 9-16)

The last line of the second stanza plays out W.J.T. Mitchell's conclusions about "ekphrasis and the other" (Mitchell 695-719). What Mitchell calls "ekphrastic indifference" occurs as the poet strolls, guidebook in hand, and becomes enveloped with a sense of calm. In this dream-like state, the figures and still lives in the art works appear frozen in the first stanza, and yet through prolonged viewing, they remind the poet that before their current lives, they were "violent monsters" (l. 1). Now they have, in effect, come to life, and the goals of "ekphrastic hope", of achieving vision, iconicity, or a "still moment" of plastic presence through language, become "ekphrastic fear" that may be "more than we can bear". The agent for this fear is, interestingly, "rhythm", lurking in the canvas, reminding us of the role of flux in MacNeice's poem "Poussin" (K. Brown 23-40). The poem thereby expresses the tension between movement and stasis that is central to this thematic volume. It achieves this through reference to still life, which on investigation is seen to be a trope in a number of poems by MacNeice.

The theme of immobility can be seen perhaps most intensely in the third stanza of "Picture Galleries", in which he mentions a work held in the collection of the Provincial Museum of Fine Arts in Seville. Carthusians in their Refectory by Zurbarán (the correct title of which is St. Hugo in the Refectory, c. 1655) is a remarkable choice for a favourite painting (MacNeice 1965, 159). As the figure below shows, it is a picture of extreme austerity, depicting seven monks in white, congregated around a table, on which bread, bowls of meat, and jugs are arranged. The work illustrates divine approbation relating to a decision by the monks never to eat meat. The story of the life of St. Bruno records that one Sunday the seven monks were offered meat, and while debating whether to eat it or not, they fell into a deep sleep lasting for six weeks. On their waking, St. Hugo was amazed to find the meat still there, and in the picture, St. Hugo is pictured pointing to meat transforming miraculously under his eyes into ashes. The story concludes that in view of the miracle, the monks decided to continue their abstinence from eating meat. ${ }^{9}$ Given the omission of St. Bruno from MacNeice's references to the painting, he may not have associated the work with its full iconography drawn from the life of the saint. Nevertheless, one might ask why this picture appealed so much to him?

Textual evidence for MacNeice's interest in this work dates back to 1940, when, during his convalescence in America, he wrote to Eleanor Clark:

I have also been reading in a dipping \& splashing kind of way [...] a book about Goya (some facts I need for my prose book) \& a book on Toulouse-Lautrec [...] \& Nicholas Pevsner on the birth of modern architecture; also have been looking through books of reproductions of Greco \& Matisse \& Picasso \& Zurbaran [sic] \& Grosch \& Piero Della Francesca (rediscovered one of my favourite pictures-Carthusians in their refectory by Zurbaran [sic], which I saw in Seville); also Walker Evans photographs of America. (MacNeice to E. Clark, 3 Sept. 1940, in Allison 404-405) 


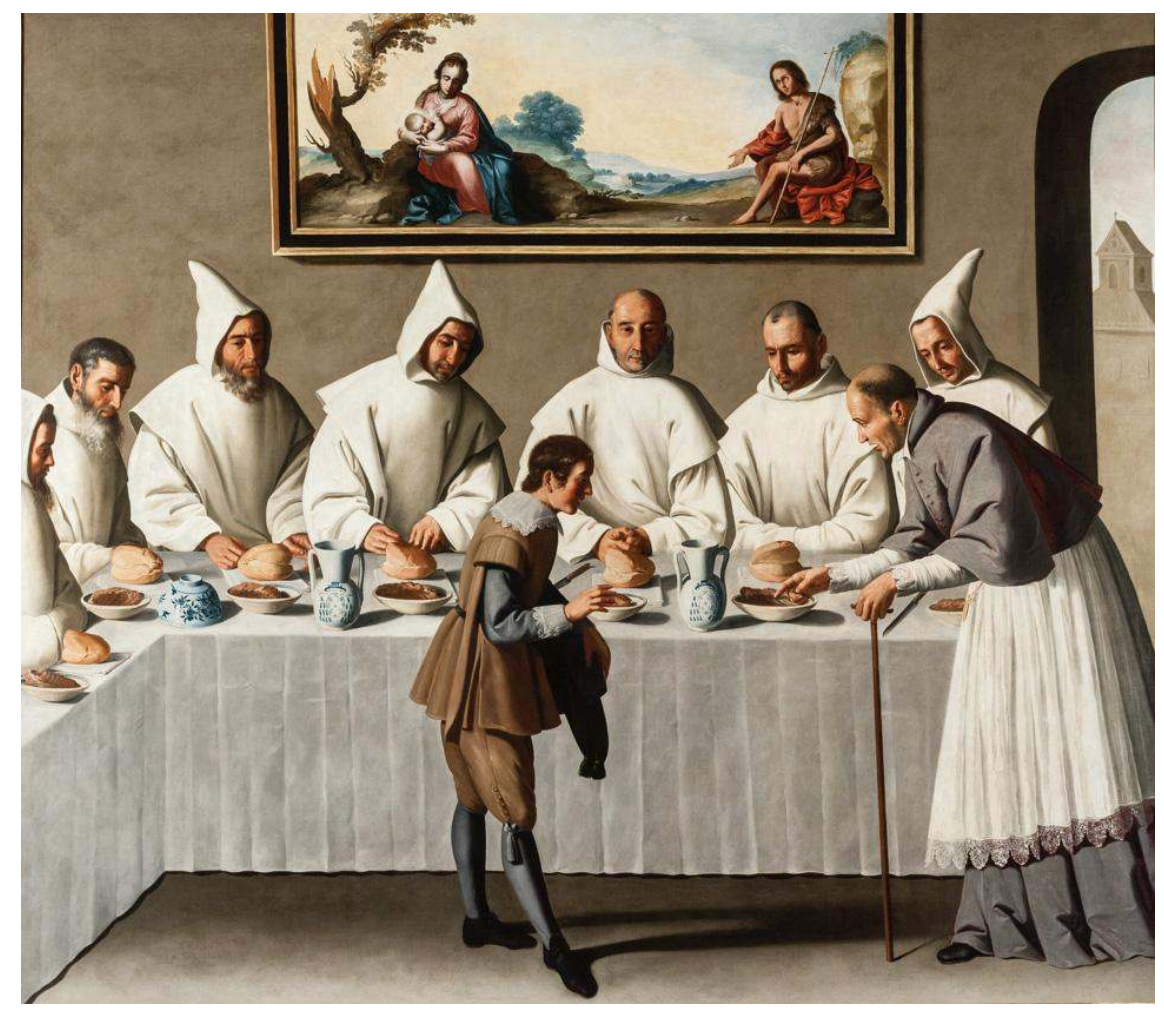

Francisco de Zurbarán, San Hugo en el Refectorio (St. Hugo in the Refectory) (c. 1655), 262 × 307 cm, oil on canvas, Seville, Provincial Museum of Fine Arts, ( ) la Consejería de Cultura de la Junta de Andalucía

Another clue lies in MacNeice's unfinished autobiography The Strings are False, in which the work is mentioned again. There, he recalls his visit to Spain with Blunt, and writes:

Our new revelation was the painting of Zurbaran [sic]. In the Museum at Seville are two pictures of his which require the word "inevitable"-bread became God but still bread. In one the Virgin Mary in a great blue robe held up like a tent by cherubs is laying her hands in blessing-and it is a blessing you believe in-on the heads of kneeling Carthusians. The other is a picture of a Carthusian refectory (those white robes were a godsend to Zurbaran [sic]), a design mainly of parallels, crockery and loaves on the table as precise as in a still-life by Chardin, and the monks in still-life too; the whole is as clean as an operating chamber where no one will ever operate; a lyrical intense placidity; a haunting matter-of-factness. (MacNeice 1965, 159)

In the context of art history, MacNeice has responded to the intense stillness of the moment captured by Zurbarán, in which the monks are poised for action (eating and drinking), and yet appear to be frozen in time, perhaps reflecting the stoicism and measure of their lives as well as their slumber. The composition of the work reinforces their alterity. The table positions the viewer at a firm remove from the main group of monks, while directing our eye from the left-hand foreground towards the main action of the canvas, which takes place in front of the table where St. Hugo greets a layman. Critic Julián Gállego considers the latter to be a page or a cook, and has written convincingly on Zurbarán's use of colour. He remarks that the colour white on the monks' habits is full of subtle ranges of tone, and that this tonality is enlivened further by the sienna suit and blue sleeves of the layman, as well as the leaden grey of St. Hugo's mozzetta [short cape with a hood] and cassock (Gállego 66-67). He describes the picture on the wall above the group as "like an orgy of colour", pointing out that it attracts our attention immediately, as do the warm loaves and blue design on the white crockery (Gállego 67). This picture on 
the wall has been identified as the "Virgin, Child and Saint John the Baptist", after a Flemish engraving known to Zurbarán (Baticle 248-251).

With regard to iconography, to admire strongly Roman Catholic imagery of a group of Carthusian monks may seem odd for a man brought up in the Protestant Church of (Northern) Ireland, and who for all accounts and purposes did not participate in formal religion as an adult. And yet, MacNeice would have been sensitive to the Catholic belief in transubstantiation ("bread became God but still bread"). Was MacNeice empathizing with Carthusian monks? If so, in what ways? The Carthusian Order was founded by St. Bruno of Cologne, who settled in 1084 with some disciples in the wild and mountainous region near Grenoble, called Chartreuse. The monks led a solitary, silent existence spent for the most part in their individual cells, which could only be left three times a day for Mass and prayers in the church (Zarnecki 101). On reflection, this lifestyle resonates with that of the poet living at a remove from society. It also resonates with MacNeice's "The British Museum Reading Room", in which a site of learning and enrichment is shared by a community of largely solitary characters living and working in a "safe and silent" space (MacNeice 2007, 690, 1. 13).

In the third stanza of "Picture Galleries", MacNeice writes that Zurbarán was acting as a "creature of the period" when he painted the monks. In the context of the poem, the reference marks a shift from the subjective to the objective as the poet retreats from his rhythmic agony experienced in stanza 2, to suggest that one can view and understand art works "as history" to "remind us of what we always / Would rather forget-":

Or viewed as history they remind us of what we always

Would rather forget-that what we are or prefer is conditioned

By circumstances, that evil and good

Are relative to ourselves who are creatures of period; seeing

That what, for instance, Zurbaran found in his Carthusians

Serene in white, with rope girdle and hood,

Lautrec discovered in brothel and circus; the answers were even

Even though we today may find them odd.

(MacNeice 2007, 760, 1. 17-24)

The stanza therefore embodies Blunt's observations on MacNeice's "astonishing visual sensibility", and also Terence Brown's view on the stoicism of MacNeice's poetry. In the context of ekphrasis, it also sees the poet keeping the speaker's relationship with art works in a state of flux or questioning, thus fashioning what Elizabeth Loizeaux has described as "the dynamic interplay of the perceiving, thinking, feeling poet, the work of art and the audience that is characteristic of ekphrasis as a literary genre" (Loizeaux 16).

As the poem progresses into stanzas 3 and 4, MacNeice meditates on the possibility of the gallery visitor being in a crowded space while also feeling very alone. Yet having promised refuge from the world, ultimately the gallery throws the poet back into the world of history, society, and politics. Most significantly, the final stanza of "Picture Galleries" introduces noise for the first time, as MacNeice realises that people have in fact surrounded him during his under-water, museal dream:

A curator rings a bell: tourists, connoisseurs and loafers,

School-children with their teachers, hustle for the door, many

of their faces tired or showing relief

At leaving a silence which was a crowd of voices, the language,

Like that of a paralytic hard to follow; they descend the staircase

Into the open air, a sheaf 
Of inklings fluttering in their minds, and now even the open

Air is half-articulate and unsafe.

(MacNeice 2007, 760-761, 1. 25-32)

the British Museum Reading Room, MacNeice responds to the particular history of the National Gallery of London during the Second World War. Founded in 1824, this gallery found its permanent home on Trafalgar Square in the 1830s, where it was strategically located to provide access to the wealthy, coming by carriage from the west end of the city, and to the working classes, coming by foot from the east end. From its earliest days, the gallery was therefore committed to democratic access for all to both building and collections; and as with the British Museum, careful plans were made for the evacuation of works in time of war. ${ }^{10}$ With the bombing of central London imminent, the Board of Trustees made the decision to evacuate the National Gallery collection to Wales, from which it would be shipped to Canada. In June 1940, however, during the Battle of France, Churchill sent a telegram to Kenneth Clark (then director of the Gallery) instructing him to "bury them in caves or in cellars [...] no pictures shall leave these islands"; and so the pictures were put into slate mines in Wales (McGregor 42-43). ${ }^{11}$ MacNeice's poem "The National Gallery" was written in celebration of the return of the pictures to Trafalgar Square in 1945:

The kings who slept in the caves are awake and out,

The pictures are back in the Gallery; Old Masters twirl their cadenzas, whisper and shout,

Hundreds of windows are open again on a vital but changeless world-a day-dream free from doubt.

[...]

So fling wide the windows, this window and that, let the air

Blowing from times unconfined to Then, from places further and fuller than There,

Purge our particular time-bound unloving lives, rekindle a Pentecost in Trafalgar Square.

(MacNeice 2007, 258-259, 1. 1-5, 43-47 respectively)

Through these encounters with paintings, the musing poet finds himself momentarily lifted out of his perambulation through the gallery. Pictorial characters come to life in his poem in a form of energeia, which, if we understand the word in its ancient meaning, describes the way that characters and stories come to life in the mind's eye of the reader. As elaborated by Liliane Louvel, energeia effectively gives the silent artwork the capacity to speak, speaking in its silence (Louvel 43, 177, 186-187). MacNeice's Old Masters vividly come to life in the mind of the poet when they "twirl their cadenzas, / Whisper and shout" (MacNeice 2007, 258, 1.2-3). We can recognise herein the idea that Plutarch 
attributed to Simonides in the Moralia, and to which Giorgio Agamben draws attention in his discussion of silence, text and the visual image. This is the idea that painting can be comprehended as "silent poetry" (poiēsis siōpōsa), and poetry as "painting that speaks" ( zōgraphia lalousa) (quoted in Agamben 96).

The gallery visit has, in this instance, effectively engendered a synaesthesic experience resulting in a cacophony of voices that we find in the poem "Pentecost" (MacNeice 2007, $259,1.47)$. Beyond these formal and sense-directed interpretations of this poem, however, MacNeice engages with the didactic function of the museum as an institution. His experience has altered his understanding of the world, signifying the redemptive possibilities for society in times of strife. This conveys the message that pictures can speak in many tongues, and to many people. Entering the museum, visitors expect an uplifting and quasi-religious experience: one that has the potential to alter the way that one sees the world. In the words of Frank Pick in 1938, a museum should be a "storehouse of the imagination [...]. A visitor should feel the real value of the National Gallery when he comes out, because he should come out with a new vision not of the past but of the present, and see something fresh about Trafalgar Square" (Pick 95). This is the new vision noted in MacNeice's "The National Gallery".

To conclude, in his museum and gallery poems, MacNeice fashions himself as a beetle scurrying into the refuge of the museum ("Museums"); as an escapist entering a still and dreamlike state ("Picture Galleries"); or as a member of a community of scholars living at remove from society ("The British Museum Reading Room"). Focusing specifically on his poems about museums and galleries informs our understanding of him as a poet engaged with the museum as the place of intense immobility and working within the ut pictura poesis tradition. These concerns are important in ongoing debates about MacNeice's position in relation to 1930s British and Irish poetry, politics, religion, and philosophy. He was part of the Auden generation of sceptics and stoics, but ultimately MacNeice has been revealed as a poet who believed in the redemptive possibilities of poetic endeavour. Understood in socio-historical context, these ideas resonate not only with what we know of MacNeice's personal biography, but also with the matrix of historical pressures that he faced between the Wars. On the eve of the Second World War, the British Museum Reading Room provided a silent refuge for writers and vagrants alike, and when he travelled to the USA, MacNeice experienced personal and poetic elevation inspired in significant measure by picture galleries. For him, the museum was at once a temple, a mausoleum, and a sanctuary in which the poet could experience the suspension of time. At times the museal space was experienced as troubling immobility, but it was a suspension out of which one would ultimately emerge regenerated and reaffirmed to face a noisy world.

\section{BIBLIOGRAPHY}

Agamben, Giorgio. “Image and Silence”. Diacritics 40.2 (Summer 2012): 94-98.

Allison, Jonathan. Letters of Louis MacNeice. London: Faber and Faber, 2010. 
Alpers, Svetlana. “A Way of Seeing”. Exhibiting Cultures: The Poetics and Politics of Museum Display. Ivan Karp and Steven D. Lavine (eds.). Washington, DC: Smithsonian Institution Press, 1991, 25-32

Auden, W.H. “Musée des Beaux Arts". Collected Poems [of] W.H. Auden. Edward Mendelson (ed.). London: Faber and Faber, 1976, 146-147.

Baticle, Jeannine. Zurbarán. Paris: Éditions de la Réunion des Musées Nationaux, 1988.

Bazin, Germain. The Museum Age. Brussels: Desoer, 1967.

Bennett, Tony. The Birth of the Museum: History, Theory, Politics (1995). London: Routledge, 2007.

Brearton, Fran, and Edna Longley (eds.). Incorrigibly Plural. Louis MacNeice and his Legacy.

Manchester: Carcanet, 2012.

Brown, Karen E. "Poems after Poussin: MacNeice, Yeats and Durcan in the National Gallery of Ireland". Musing in the Museum. Special issue of Word \& Image: A Journal of Verbal/Visual Enquiry 30.1 (2014): 23-30.

Brown, Karen E., Laurence Petit, and Liliane Louvel (eds.). "Introduction". Musing in the Museum. Special issue of Word \& Image: A Journal of Verbal/Visual Enquiry 30.1 (2014): 2-6.

Brown, Terence. Louis MacNeice: Skeptical Vision. Dublin: Gill and MacMillan, 1975.

Caygill, Marjorie. The Story of the British Museum. London: British Museum Publications, 1981.

Chambers, Robert \& William. The Chambers Dictionary (1872). Edinburgh: Chambers, 2006.

Coombes, John E. "Constructing the Icarus Myth: Brueghel, Brecht and Auden". Word \& Image: A Journal of Verbal/Visual Enquiry 2.1 (1986): 24-26.

Crook, J. Mordaunt. The British Museum. London: Allen Lane, 1972.

Duncan, Carol. "Art Museums and the Ritual of Citizenship". Exhibiting Cultures: The Poetics and Politics of Museum Display. Ivan Karp and Steven D. Lavine (eds.). Washington, DC: Smithsonian Institution Press, 1991, 88-103.

Flaxman, Rhoda L. Victorian Word-Painting and Narration: Toward the Blending of Genres. Ann Arbor, Michigan: UMI Research Press, 1983.

Gállego, Julián. Zurbarán, 1598-1664. Biography and critical analysis by Julián Gállego; catalogue of the works by José Gudiol; translated from the Spanish by Kenneth Lyons. London: Secker and Warburg, 1977.

Greenblatt, Stephen. "Resonance and Wonder". Exhibiting Cultures: The Poetics and Politics of Museum Display. Ivan Karp and Steven D. Lavine (eds.). Washington, DC: The Smithsonian Institution Press, 1991, 42-56.

Hopkins, Viola. "Visual Art Devices and Parallels in the Fiction of Henry James". PMLA 76.5

(December 1961): 561-574.

Hudson, Kenneth. Museums of Influence. Cambridge: Cambridge UP, 1987.

Hynes, Samuel. The Auden Generation: Literature and Politics in England in the 1930s. London: Random House, 2011.

Johnston, Maria. “'This Endless Land': Louis MacNeice and the USA”. Irish University Review: A Journal of Irish Studies 38.2 (2008): 243-262.

Krieger, Murray. Ekphrasis: The Illusion of the Natural Sign. Baltimore: Johns Hopkins UP, 1992. 
Loizeaux, Elizabeth Bergmann. Twentieth-Century Poetry and the Visual Arts. Cambridge: Cambridge UP, 2008.

Longley, Edna. “No More Poems about Paintings?” The Living Stream: Literature and Revisionism in Ireland. Newcastle: Bloodaxe Books, 1994, 227-251.

Louvel, Liliane. Poetics of the Iconotext. Karen Jacobs (ed.), Laurence Petit (trans.). Aldershot: Ashgate, 2011.

MacNeice, Louis. Zoo. London: M. Joseph, 1938.

MacNeice, Louis. Poems, 1925-1940. New York: Random House, 1940.

MacNeice, Louis. The Strings are False: An Unfinished Autobiography. London: Faber and Faber, 1965. MacNeice, Louis. The Collected Poems of Louis MacNeice. E. R. Dodds (ed.). London: Faber and Faber, 1966.

MacNeice, Louis. Collected Poems. Peter McDonald (ed.). London: Faber and Faber, 2007.

Mansfield, Elizabeth (ed.). Art History and its Institutions. London: Routledge, 2002.

McGregor, Neil. "A Pentecost in Trafalgar Square”. Whose Muse? Art Museums and the Public Trust. James Cuno (ed.). Princeton: Princeton UP, 2003, 27-48.

Miller, Edward. That Noble Cabinet: A History of the British Museum. London: Andre Deutsch, 1973.

Mitchell, W.J.T. “Ekphrasis and the Other". South Atlantic Quarterly 91 (Summer 1992): 695-719.

Paul, Catherine. Poetry in the Museums of Modernism: Yeats, Pound, Moore, Stein. Ann Arbor, Michigan: U of Michigan P, 2002.

Pick, Frank. "The Function of the National Gallery”. Burlington Magazine for Connoisseurs 72 (Feb. 1938): 95.

Presiosi, Donald. "Hearing the unsaid: art history, museology and the composition of the self". Elizabeth Mansfield (ed.). Art History and its Institutions. London: Routledge, 2002, 28-45.

Sim, Stewart. Manifesto for Silence. Confronting the Politics and Culture of Noise. Edinburgh: Edinburgh UP, 2007.

Stallworthy, Jon. Louis MacNeice. London: Faber and Faber, 1995.

Steiner, Wendy. The Colours of Rhetoric: Problems in the Relation between Modern Literature and Painting. Chicago: Chicago UP, 1982.

Steiner, Wendy. Pictures of Romance: Form against Context in Painting and Literature. Chicago: Chicago UP, 1988.

Walker, Tom. "Even a Still Life is Alive: Visual Art and Bloomsbury Aesthetics in the Early Poetry of Louis MacNeice". The Cambridge Quarterly 38.3 (2009): 196-213.

Walker, Tom. Louis MacNeice and the Poetry of His Time. Oxford: Oxford UP, 2015.

Wilson, David M. The British Museum: A History. London: British Museum Press, 2002.

Yeats, W.B. The Variorum Edition of the Poems of W.B. Yeats. Peter Allt and Russell K. Alspach (eds.). New York: Macmillan, 1966.

Zarnecki, George. The Monastic Achievement. London: Thames and Hudson, 1972. 


\section{NOTES}

1. King's College, Cambridge, Frederick Louis MacNeice archive (FLM), FLM 1/2/2 (9 Jan. 1927); FLM 1/2/2 (17 Nov. 1927); FLM 1/2/3 (13 Feb. 1928); FLM 1/2/4 (27 Mar. 1929).

2. FLM 1/2/1 (14 Oct. 1926); FLM 1/2/2/ (9 Jan. 1927); FLM 1/2/1 (9 Jan. 1927); FLM 1/2/2 (29 Mar. 1927).

3. FLM $1 / 2 / 6$ (17 Nov 1934).

4. FLM 2/1. MacNeice also wrote: "Anthony and I went in for eclectic reading; it was either stark and realistic or precious and remote and two-dimensional. We read Tolstoy and Dostoievski [sic] and Beckford's Vathek, Thomas Hardy and Crébillon fils, Blake and Lucretius and books about Blake and Lucretius, [repetition in original], lives of Cézanne and Van Gogh, the three Sitwells, Lord Dunsany's fairy stories, Edward Lear and T.S. Eliot and Aldous Huxley. Anthony had a flair for bigotry: every day he blackballed another musician; despised Tennyson, Shakespere [sic], the Italian High Renaissance and Praxitiles, was all in favour of the Primitives, of Uccello, of the Byzantine mosaics, of Breugel [sic] and Negro sculpture" (qtd in Stallworthy 180).

5. MacNeice's relationship with the "Auden generation" of poets is well known (Hynes; Brearton \& Longley xii).

6. Kenneth Hudson cites the Library of Congress in Washington (1897) and the Prussian State Library in Berlin (1914) as the most famous "children" of the British Museum Round Reading Room (26). For a history of the architectural design, see Crook 175-182.

7. For a recent discussion of MacNeice's love poem for Clark, see Peter McDonald "The Pity of It All", in Brearton \& Longley (1-24). For a discussion of the pivotal nature of MacNeice's time in the USA, see Johnston 10-11.

8. "Picture Galleries" first appeared in MacNeice's Poems 1925-1940, 1940. In the editorial notes to MacNeice's Collected Poems, Peter McDonald indicates that it "was included in Plant and Phantom, between 'London Rain' and 'Trilogy for X”' (MacNeice 2007, 817). McDonald places the poem in Appendix 5, "Uncollected Poems 1932-1963".

9. This iconography is recorded in Zurbarán (Gállego 248), and is drawn from the second part of the life of St. Bruno (1596, folios 146-149).

10. When the Munich crisis foretold of war, fifty paintings were transported to Bangor, Wales, and all paintings were removed during the ten days preceding the declaration of war on 3 September 1939.

11. One of the first works to return was Charles I on Horseback by Van Dyck (c. 1637-38).

\section{ABSTRACTS}

This essay brings into focus letters and poems by Louis MacNeice (1907-1963) that engage with the museum as a place of silence, stillness, and refuge. From memories of the British Museum formed in his youth to encounters with art institutions in Britain and the USA, it looks afresh at four poems reflecting on the intense immobility of the museum experience: "Museums" (1933), "The British Museum Reading Room" (1939), "Picture Galleries" (1940), and "The National Gallery" (1945). These poems are read here in literary critical terms in relation to the history and theory of ekphrasis, and museology. The aim in so doing is to pursue these references as a poetics 
of stillness and refuge in the face of upheaval, both personal and societal. The essay shows how MacNeice offered both a critique of the immobility such retreat engendered, and an appreciation of its space of refuge, indicating that the museum was for him a layered or deeply resonant trope. Themes to emerge include voices of silence in the museal space, idleness and temporality in the ekphrastic encounter, enargeia and, ultimately, inspiration and Pentecost. In his words from "Autumn Sequel, Canto VIII", MacNeice put the issue succinctly: "So to the galleries: to escape mankind / By rediscovering it" (MacNeice 2007, 409, 1. 77).

Cet article se concentre sur des lettres et des poèmes de Louis MacNeice (1907-63) qui abordent le musée comme lieu-refuge, de silence et d'immobilité. Des souvenirs du British Museum accumulés dans sa jeunesse jusqu'à ses découvertes des institutions muséales de GrandeBretagne et des États-Unis, l'article se penche sur quatre poèmes méditant sur l'«immobilité vive » qu'est l'expérience du musée : « Museums » (1933), "The British Museum Reading Room » (1939), «Picture Galleries » (1940), and «The National Gallery » (1945). Ces poèmes sont relus ici en termes d'analyse littéraire, en lien avec l'histoire et la théorie de l'ekphrasis, et la muséologie. Le but que se donne cette analyse est de retracer dans ces références une poétique de l'immobilité et du refuge face aux événements affectant l'individu, tout comme l'ensemble de la société. L'article montre comment MacNeice offre à la fois une critique de l'immobilité engendrée par ce type de retraite hors du monde et une appréciation du lieu-refuge, qui montrent combien le musée était pour lui un trope aux multiples implications et aux multiples échos. Les thèmes qui se dégagent de cette analyse sont ceux des voix silencieuses de l'espace muséal, de la contemplation et de la temporalité de la rencontre ekphrastique, de l'enargeia, et finalement de l'inspiration et de la révélation de la Pentecôte. MacNeice résuma ainsi le sujet, dans le poème "Autumn Sequel, Canto VIII": «Allons visiter les musées pour échapper à l'homme / et le redécouvrir» (MacNeice 1966, 364, v. 77).

\section{INDEX}

Keywords: museum, word/image, ekphrasis, museum-mausoleum, stillness, temporality, refuge, wartime

Mots-clés: musée, texte/image, ekphrasis, musée-mausolée, immobilité, temporalité, refuge, guerre

\section{AUTHORS}

\section{KAREN BROWN}

Karen Brown is Lecturer in Art History \& Museum and Gallery Studies at the University of St Andrews. She is Director of the School of Art's Museums, Galleries and Collections Institute. She joined the School in 2013 from the University of Cambridge and Trinity College, Dublin, where she was a Marie Curie Postdoctoral Research Fellow. From 2016-2020 she is co-ordinating a new research project funded by the European Commission Horizon 2020 programme called "EU-LACMUSEUMS: Museums and Community: Concepts, Experiences, and Sustainability in Europe, Latin America and the Caribbean". Her research interest in museums is international and interdisciplinary, concerning relationships between museums, their communities and the environment, as well as the visual arts and literature. Her teaching interests also include the history and ethics of museums and collecting, university collections and museums, women artists, and Irish art. She was for eight years a Board Member of ICOM-Ireland, and currently serves on the Board of the European Regional Alliance of ICOM. Karen first studied History of Art 
and Architecture with French at Trinity College, Dublin, after which she worked as a university Curator of Art. 